\title{
Corporate strategy comparison Walt Disney and Oriental Land
}

Megumi Nakajima (Deaprtment of Management, Tokyo Management Collage, meguminnie@white.plala.or.jp)

\begin{abstract}
The purpose of the paper is corporate strategy comparison Walt Disney Company and Oriental Land Corporation. These firms manage Disney theme parks in America and Japan. Both of them are successful. However, they have different policy, organization, ability, history, corporate culture, corporate philosophy. Many people think both firms are similar company and have similar strategy. However, they have different strategies. Running Disneyland needs different strategy if they are located in different countries. That means running successful Disneyland in developed countries needs different strategies. Walt Disney is a movie production in Hollywood, and their evaluation is only box office in America. Walt Disney is performance based evacuation. They are extremely talent oriented. Their main business had been movie since establishment by Walt Disney. He diversified to theme park business, that is Disneyland. On the other hand, Oriental Land was established as a joint venture of two Japanese firms, Keisei Railway and Mitsui Fudosan. They still keep Japanese Management System, and Japanese 'salary man'work for Oriental Land. The two firms are based on these background, they have different policy, human resource system, evaluation system, and strategy. Core strategy of Walt Disney is diversification and second use of character and movie contents to gain synergy effect. Core strategy of Oriental Land is production of nonDisney Contents, non-theme park business, and new business out of Maihama area.
\end{abstract}

\section{Keywords}

Walt Disney Company, Oriental Land Corporation, corporate strategy, organizational culture, synergy effect

\section{Introduction}

The purpose of the paper is a comparison of corporate strategy of Walt Disney Company and Oriental Land Corporation. I will discuss about it through their policy, organization, ability, history, philosophy, performance, origination, financial states and so on. Many people think both firms are similar company and have similar strategy. However, they have different strategies. Running Disneyland needs different strategy if they are located in different countries. That means running successful Disneyland in developed countries needs different strategies. They are major firms in theme park industry and have huge sales. Comparison studies of strategy of these two firms have not performed yet.

The methodology is multiple case studies. Multiple cases would figure out differences and characteristics.

Definition of corporate strategy in the paper is that how to create new value from different corporate resources to gain competitive advantage.

\section{Description of Walt Disney Company}

The Walt Disney Company is a media conglomerate with five major sections. They have (1) Media Network Section (TV station), (2) Parks \& Resorts Section (theme parks \& hotels), (3) Studios Entertainment Section (movies), (4) Consumer Products Section (Disney goods manufacturing and sales), (5) Interactive/Media Section (games). Walt Disney has about 3 billion dollars' capital, about 2,700 million issued stocks, 8,800 dollars consolidated operating profit, about 150 thousand employees. Parks and Resorts Section started at the open of Disneyland in Anaheim, California in June 17th. 1955. A Walt Disney's sub- sidiary, Walt Disney Parks and Resorts developed as a leading firm of family trip and family entertainment industry. Disney Cruise Line has four huge ships. Disney Vacation Club has eleven assets and more than 500 thousands of individual members.

Table 1 shows the selected financial data such as statements of revenue and net income. Their revenue is about 52 billion dollars in 2015, about 49 billion dollars in 2014, up to 40 billion dollars every year. Their net income is about 8.8 billion dollars in 2015 .

Table 1: Selected Financial Data (Statements of income) (in millions, except per share data)

\begin{tabular}{lcccc}
\hline & 2015 & 2014 & 2013 & 2012 \\
\hline Revenues & $\$ 52,465$ & $\$ 48,813$ & $\$ 45,041$ & $\$ 42,278$ \\
\hline Net income & 8,852 & 8,004 & 6,636 & 6,173 \\
\hline
\end{tabular}

Note: Walt Disney HP '2015 Annual Report' on page 24 March 18th 2016 accessed, https://ditm-twdc-us.storage.googleapis.com/2015Annual-Report.pdf.

Table 2 shows the business segments results 2015 of media network, parks \& resorts, studio entertainment, consumer products, interactive/media. Their biggest revenue is media networks $(\mathrm{ABC})$, their second revenue is parks and resorts (theme parks and hotels), their third revenue is studio entertainment (movie). Their main five businesses and value make a synergy effect.

Figure 1 shows graphically revenue and segment operating income of the five segments. According to the figure 1, the ratio of revenue is concentrated in media networks (TV station, $\mathrm{ABC}$ ) and parks \& resorts (theme parks and hotels). Next, studio entertainment (movie) is highly performed.

ABC is taken over by Walt Disney in 1996, and then, Walt 
Table 2: Business Segments Results 2015 (in millions dollars)

\begin{tabular}{lcc}
\hline & Revenues & Segment operating income \\
\hline Media Networks & 23,264 & 7,793 \\
\hline Parks and Resorts & 16,162 & 3,031 \\
\hline Studio Entertainment & 7,366 & 1,973 \\
\hline Consumer Products & 4,499 & 1,752 \\
\hline Interactive & 1,174 & 132 \\
\hline \multicolumn{1}{c}{ Total } & 52,465 & 14,681 \\
\hline
\end{tabular}

Note: Reverenced: Author originally made by Walt Disney HP '2015 Annual Report' on page 31 March 18th 2016 accessed, https://ditmtwdc-us.storage.googleapis.com/2015-Annual-Report.pdf.

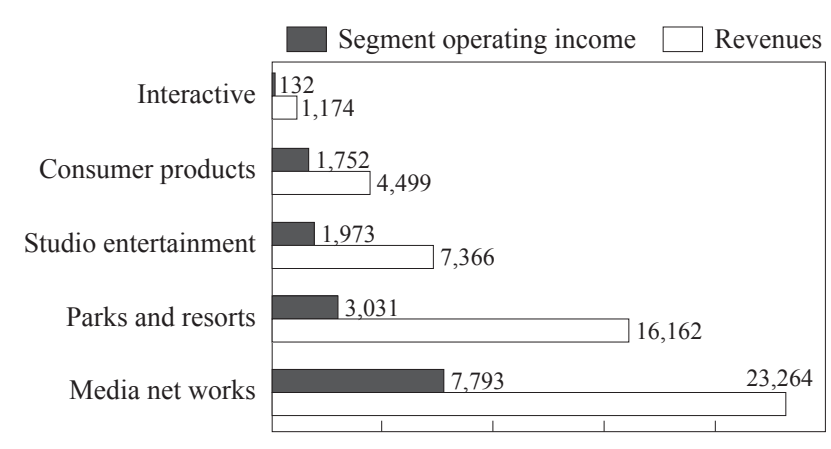

Figure1: Business Segments Results 2015 of Walt Disney Note: Author original.

Disney became a huge conglomerate and a member of Dow Jones 30. Dow Jones 30 means top 30 firms in New York Stock Exchange. Those firms make America a top country all over the world. Walt Disney is a representative firm of America.

\section{Description of Oriental Land}

Oriental Land Co., Ltd. was established in 1960 by building on reclaimed land the biggest leisure facility in Asia. Tokyo Disneyland opened in 1983, Tokyo Disney Sea opened in 2001 [Oriental Land, 2016a]. Oriental Land has three segments, (1) theme parks, (2) hotels, (3) other business (concretely, shopping center, IKSPIARI, monorail, Disney Resort Line, restaurants and so on).

Head quarter of Oriental Land is located in Maihama, Urayasu City, Chiba near downtown Tokyo. Its business partner is Disney Enterprises, Inc. Their achievement is about 644 billion yen, about 110 billion yen operating income, about 110 billion yen ordinary incomes, about 7 billion yen net income (as of March 31, 2015). Their major shareholders are Keisei Electric Railway, Mitsui Fudosan, Chiba Prefecture. They have 17 consolidated subsidiaries (as of September 1, 2015). They are listed on Tokyo Stock Exchange, First section [Oriental Land, 2016b].

Their two theme parks had 31,377 million gests in 2014 . Average per guest sales is 10,955 yen, ticket sale is 4,660 yen, goods sales is 4,043 yen, food and beverage sales is 2,252 yen. Their sales are 387 billion yen. Hotel business sales are about
610 billion yen. Guest room usage ratio was late $90 \%$ of Tokyo Disney Sea Hotel Mira Costa, and it was mid $90 \%$ in Tokyo Disneyland Hotel and Disney Ambassador Hotel. Their operating profit was about 13 billion yen. The sales of the monorail were about 17.6 billion yen. The sales of the shopping center were 1.6 billion yen.

Table 3 and Figure 2 show that the ratio of segment sales. About $83.1 \%$ of consolidated sales is theme park segment, hotel is $13 \%$, other business (shopping center and monorail) is 3.7 $\%$. Figure 2 is understandable that theme park business is a big ratio of sales. Hotels and other business cannot be major parts of Oriental Land.

Table 3: Consolidated Segment Sales 2014 (in Japanese yen)

\begin{tabular}{lcc}
\hline \multicolumn{1}{c}{ Segment } & Sales & Ratio \\
\hline Theme Park & 387.622 billion & $83.1 \%$ \\
\hline Hotel & 61.066 billion & $13.0 \%$ \\
\hline Other Business & 17.603 billion & $3.7 \%$ \\
\hline Total & 466.291 billion & $100 \%$ \\
\hline
\end{tabular}

Source: Oriental Land Annual Report 2014.

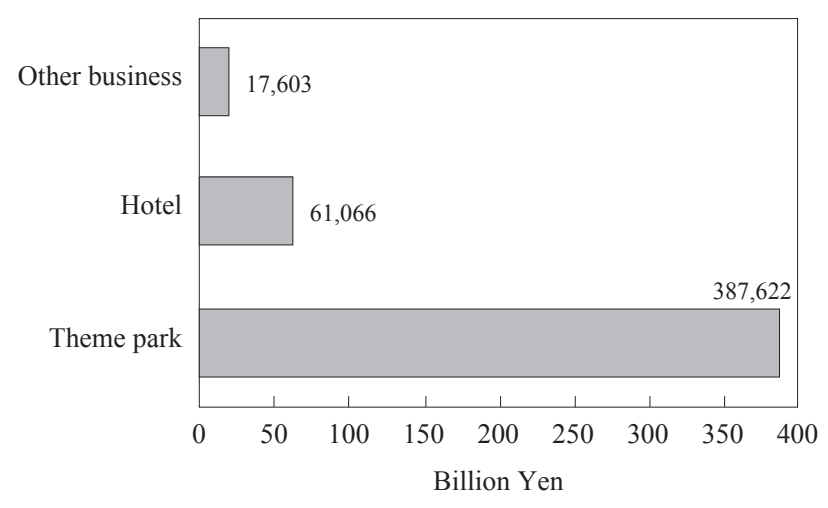

Figure 2: Business Segments Results 2014 of Oriental Land (in billion yen)

Note: Author original.

\section{Corporate culture of Walt Disney is Hollywood}

Corporate culture of Walt Disney is Hollywood. Many of movie firms have developed various diversifications. Originality and creativity are important in Hollywood. All things are decided in an informal human relationship in Hollywood. Hollywood is a closed world. The people start their career from the bottom of hierarchy. Just a few people can move up to higher steps. Other people and other firms cannot enter into Hollywood easily. They do not work with the company; they work with the person in Hollywood. Hollywood has a high entry barrier [Eisner and Schwartz, 1998].

For example, Chairman Wasserman of MCA was called 'Emperor of Hollywood'. He started his career as a ticket collector at a theater. He nurtured a filmmaker, Steven Spielberg and many of big names. Spielberg takes royalty for Wasser- 
man. Spielberg worked with MCA if Wasserman was there. Bronfman started his career as an assistant of movie director at age 16, and then, he became a chairman of Universal Studios. Michael Ovitz started his career as an assistant of actor production, and then, he became 'No.1 Man of Hollywood'. Michael Eisner started his career as an assistant of TV station, and then, he became a chairman and CEO of Walt Disney. He was called 'Emperor of Disney'. Many people from all over the world challenge something in Hollywood. They do the tough works at the bottom of hierarchy with low salary, and then give up and quit. Success in Hollywood is much more powerful and gorgeous than success in NY and Washington DC. Hollywood is a symbol of American Dream.

Hollywood BIG 6 is Walt Disney, Warner Brothers, 20th Century FOX, Universal Studios, Paramount, and SONY Entertainment (former Colombia). Hollywood has an extreme merit system. They always depend on box office. Their merit means the number of audience and box office. How much each movie earns. Quality of movies does not matter. Low box office movies are failure; high box office movies are success even though low quality movies. However, less movies make much money. The most movies cannot make money. Just little movies are surplus, and most movies are deficit. So surplus of successful movies make up the deficit of failed movies. Therefore, small-and-medium sized firms often go bankrupt. Movie productions often merger and make them bigger firms. Movie productions are always absorbed by the most powerful firms. Huge firms can absorb the deficit of failed movies. Movie productions become a section of a huge firm (Eisner and Schwartz, 1998).

Core strategy of Walt Disney is using contents of movies and characters. The source of competitive advantage of Walt Disney is, (1) legal section, and (2) Imagineer, according to Toshio Kagami (2003), Chairman of Oriental Land. The legal section means lawyers. They expanded contents business internationally with knowledge of lows. Imagineer is a coined word, imagination and engineer, Walt Disney created. Imagineers work for The Walt Disney Imagineering Company (Imagineering Company). Imagineering Company is a subsidiary firm of Walt Disney, they develop attractions, parades, hotels and so on. In Walt Disney's Time, they diversified cartoon business to character goods business and theme park business. In Michael Eisner's Time, they absorbed the TV station, ABC and infoseek, and then, they became a huge media conglomerate. And Walt Disney became a member of Dow Jones 30 which are representative firms of American economy. Purpose of diversification is scope of economies and synergy effect, and risk diversification.

\section{Overcome weak points of Oriental Land}

Disney Contents such as Mickey Mouse in Tokyo Disney Resort look Oriental Land's resource, but they are Walt Disney's resource. Oriental Land is a developer firm which made a license contract of Disney Contents usage with Disney En- terprises, Inc., and pays a royalty fee. Oriental Land has three week points, (1) Disney dependency, (2) theme park business dependency, (3) Maihama all-concentration.

(1) Disney dependency means that Disney Contents such as characters and theme parks are used in Tokyo Disney Resort, they earn about $83 \%$ of benefit. Their hotels with Disney Contents earn about $17 \%$. Ratio of sales of NonDisney Contents is about $3 \%$.

(2) Theme park dependency means that about $83 \%$ of Oriental Land's sales and benefit is generated from two theme parks, Tokyo Disneyland and Tokyo Disney Sea. Oriental Land started new businesses of Non-Disney Contents such as Cirque du Soleil, Camp Nepos, IKSPIARI. However, new businesses are still low profitability. For instance, Cirque du Soleil evacuated just in three years.

(3) Maihama all-concentration means that a tiny area, Maihama has almost all resources such as Tokyo Disneyland, Tokyo Disney Sea, hotels, a shopping mall, a monorail. If the area was visited by serious natural disaster, they would lose almost all resources. Actually, the great earth quick damaged the area in 2011, and they are closed more than one month.

Countermeasures for threats, (1) production of Non-Disney Contents, (2) production of non-theme park business, (3) launch for other area. Concretely, (1) shopping center, IKSPIARI, child care and education center, Camp Nepos (already withdraw), alliance with entertainment restraint, Rain Forest Café, (2) management of a monorail, Disney Resort Line, hotels, bridal business, Disney Fairy Tale Wedding and Disney Royal Dream Wedding, acquisition of Disney Store's management right, (3) takeover of Kyoto Brighton Hotel, hotel management in other area of Urayasu City, food theme park management in Canal City Hakata (plan canceled), theater management of Cirque du Soleil near Osaka Station (plan canceled), restraint management in Tokyo and Chiba (Non-Disney Contents), close down of unprofitable Disney Stores. Oriental Land has been making a lot of efforts but they cannot make profitable business except for theme parks or hotels. They need some successful businesses of Non-Disney Contents [Nakajima, 2013].

\section{Comparison Walt Disney and Oriental Land}

Table 4 shows a comparison Walt Disney and Oriental Land. The top management of Walt Disney is specialists of movie production such as movie producers and filmmakers. They are winner of Hollywood and a symbol of American dream. Also, Hollywood is a symbol of creativity, the most florid job all over the world. Movie is more important than theme park in Walt Disney. They train creativity and originality. They are drastically talent based, performance based but challenging and gambling culture. They fund to gain money to sell dream and longing. Hollywood is always hyper competition, and always new faces come from all over the world. New people try in 
Hollywood.

On the other hand, the top management of Oriental Land is Japanese 'salary man'. Salary man means the white collar office workers in Japanese society. They are hired with a human resource system, life time employment. They seriously depend on firms. If their firms are highly performed, they are stably hired with higher salary. But if their firms are low performed, firms often downsize salary and number of employees. Japanese salary men need ability to get a stable position and salary in firm. Therefore, salary men are usually quiet and obedient. Their culture does not match creativity and originality.

The initial members to create Tokyo Disneyland transferred from a real estate firm, Mitsui Fudosan and a railway firm, Keisei Electric Way. Oriental land is a joint company of those two firms. When they started to build Tokyo Disneyland, a talented producer of Dentsu, advertising agency, art and sound directors of Toho and Shiki Theatre were recruited for the initial stage of building Tokyo Disneyland. Later Oriental Land recruited new graduate students, and gradually became a popular firm for young people. Oriental Land was listed on the first section of Tokyo Stock Exchange. They have a Japanese management system such as life time employment, seniority wage system, and company union. Cooperativeness is more important than originality. Oriental Land is quiet, not so refined compared with Walt Disney. Florid and brilliant resources are Walt Disney's resource with license contract. Oriental Land has a usage right of Disney characters such as Mickey Mouse. Those characters are not Oriental Land's resource.

Finally, core corporate strategy of Walt Disney is diversification with second use, third use of contents and to gain synergy effect. They internationally develop Disney theme parks. On the other hand, core corporate strategy of Oriental Land is to produce Non Disney Contents, non-theme park business, launch for other area.

Table 4 shows a comparison Walt Disney and oriental Land. Concretely, top management, employment system, corporate culture, and corporate strategy are compared in Table 4. These factors effect corporate strategy. Top management of Walt Disney is specialists of movie production. Creativity and originality are important, and they are extremely performance based. Layoff is regal. Always new faces threaten successful people. They are always required to produce new affairs. Creative people make new contents, and many contents make a synergy effect. And they make profit of second use, third use on contents such as cable TV, consumer products, theme park, hotels, cruising and so on. Royalty business is much more safe, no gamble characteristics. Movies are difficult to succeed. They cost too much, but often deficit. Theme park business is more stable than movies.

Oriental Land is a typical Japanese firm that has Japanese salary men. Their initial members are selected from parent companies and other show business firms. They have a usage right of Disney-Contents of Disneyland. However, $83 \%$ of their sales is generated from theme park business. Oriental Land depends on Walt Disney too much. So that, core strategy of Oriental Land is Production of Non-Disney Contents, nontheme park business, launch for other area. Maihama area has almost all resources. If serious disaster occurred there, they would lose a lot.

\section{Summary}

The purpose of the paper is corporate strategy comparison Walt Disney Company and Oriental Land Corporation. These firms manage Disney theme parks in America and Japan. Both of them are successful. However, they have different policy, organization, ability, history, corporate culture, corporate

Table 4: Comparison Walt Disney and Oriental Land

\begin{tabular}{|c|c|c|}
\hline & Walt Disney & Oriental Land \\
\hline Employment system & $\begin{array}{l}\text { Extremely performance based } \\
\text { - Layoff is regal in labor lows in USA }\end{array}$ & $\begin{array}{l}\text { Japanese style management } \\
\text { - Life time employment, seniority wage system, } \\
\text { company union }\end{array}$ \\
\hline Corporate culture & $\begin{array}{l}\text { Training of creativity and originality } \\
\text { Drastically talent based } \\
\text { Performance based but challenging } \\
\text { Fundraising to sell dream and longing } \\
\text { - Gambling } \\
\text { - New faces threaten successful people } \\
\text { - Hyper competition }\end{array}$ & $\begin{array}{l}\text { Cooperativeness more than creativity } \\
\text { Quiet, not refined } \\
\text { Florid and brilliant resources are Walt Disney's. }\end{array}$ \\
\hline Corporate strategy & $\begin{array}{l}\text { Diversification with second, third use of contents } \\
\rightarrow \text { synergy effect }\end{array}$ & $\begin{array}{l}\text { Production of Non-Disney Contents, non-theme } \\
\text { park business, launch for other area }\end{array}$ \\
\hline
\end{tabular}


philosophy. Walt Disney is a movie production in Hollywood, and their evaluation is only box office in USA. Walt Disney is performance based evacuation. Oriental Land keeps a Japanese Management System. The two firms are based on these background, they have different policy, human resource system, evaluation system, and strategy.

In consideration of the paper, core strategy of Walt Disney is diversification and second use of character and movie contents to gain synergy effect. Especially, Disney theme parks are developed internationally in Japan, France and China. Conversely, core strategy of Oriental Land is production of non-Disney Contents, non-theme park business, and new business in out of Maihama area.

However, Universal Studios in Osaka Japan and Universal Studios Singapore have highly grown in recent years. That is a threat to both Walt Disney and Oriental Land. More threats would always occur. Next issue is that, (1) more details of cases, (2) comparison Walt Disney and Universal Studios.

\section{References}

Eisner, M. and Schwartz, T. (1998). Work in progress. Hyperion.

Nakajima, M. (2013). Corporate strategy of Tokyo Disney Resort. Sankeisha.

Oriental Land (2016a). About us. http://www.olc.co.jp/en/company/. (March 18, 2016 accessed)

Oriental Land (2016b). Profile. http://www.olc.co.jp/en/company/profile/. (March 18th 2016 accessed)

(Received March 23, 2016; accepted May 26, 2016) 